\title{
Why Too Soon? Early Initiation of Sexual Intercourse Among Adolescent Females in Ethiopia: Evidence from 2016 Ethiopian Demographic and Health Survey
}

This article was published in the following Dove Press journal: International Journal of Women's Health

\author{
Ebisa Turi iD ' \\ Bedasa Taye Merga (iD ${ }^{2}$ \\ Ginenus Fekadu (iD ${ }^{3}$ \\ Amanuel Alemu Abajobir ${ }^{4}$ \\ 'Department of Public Health, Institute \\ of Health Sciences, Wollega University, \\ Nekemte, Ethiopia; ${ }^{2}$ School of Public \\ Health, College of Health and Medical \\ Sciences, Haromaya University, Harar, \\ Ethiopia; ${ }^{3}$ Clinical Pharmacy Unit, \\ Department of Pharmacy, Institute of \\ Health Sciences, Wollega University, \\ Nekemte, Ethiopia; ${ }^{4}$ Maternal and Child \\ Wellbeing Unit, African Population and \\ Health Research Centre, Nairobi, Kenya
}

Correspondence: Ginenus Fekadu Clinical Pharmacy Unit, Department of Pharmacy, Institute of Health Sciences, Wollega University, Nekemte, Oromia, Ethiopia

Tel $+25 \mid$ 917|37|45

Fax +25I 576617980

Email take828pharm@gmail.com
Background: Early sexual initiation - sexual activity that begun earlier than 18 years of age - is among risky sexual behaviors which may be associated with increased risks of adverse outcomes such as sexually transmitted infections (STIs), unwanted pregnancy and unsafe abortions. However, there is no nationally representative evidence on early initiation of sexual intercourse and its determinant factors among adolescent females in Ethiopia.

Methods: Data were extracted from the 2016 Ethiopian Demographic and Health Survey (EDHS) to assess early initiation of sexual intercourse and factors contributing to it in adolescent females. The analysis included a weighted sample of 3881 adolescent females aged 15-19 years. A multivariable logistic regression analysis was conducted and the results were presented as adjusted odds ratio (AOR) at 95\% confidence interval (CI), declaring statistical significance at a p-value $<0.05$ in all analyses.

Results: About 1 in 5 (21.9\%, 95\% CI: 20.5\%, 23.33\%) adolescent females experienced early sexual debut. Administrative regions (Amhara, AOR = 2.3, 95\% CI: 1.30, 4.09 and Gambella, AOR $=4.89$, CI 95\%: 1.08, 22.07), religion (Muslim, AOR $=1.76,95 \%$ CI: 1.24, 2.49), substance use (e.g., ever chewed khat, $\mathrm{AOR}=2.02,95 \% \mathrm{CI}: 1.47,2.77$, ever drunk alcohol, $\mathrm{AOR}=1.83,95 \% \mathrm{CI}: 1.35,2.48)$ and having no knowledge on family planning $(\mathrm{AOR}=4.47,95 \% \mathrm{CI}: 2.22,8.99)$ were found to have statistically significant association with early sexual debut in adolescent females. Whereas any levels of formal education decreased the odds of early sexual debut (primary, AOR $=0.44,95 \%$ CI: $0.35,0.56$; secondary, $\mathrm{AOR}=0.19,95 \% \mathrm{CI}: 0.13,0.28$, and higher, $\mathrm{AOR}=0.31,95 \% \mathrm{CI}: 0.15,0.63$ ). Similarly, all categories of wealth indices as compared to the poorest were protective of early sexual initiation in adolescent females $(\mathrm{AOR}=0.40-0.57)$ as was for education as compared to no education $(\mathrm{AOR}=0.19-0.44)$.

Conclusion: A significant proportion of adolescent females initiate early sexual intercourse in Ethiopia and multifaceted factors appear to determine their early sexual experiences. Contextualized interventions including strengthening information, education and communication on adverse consequences of early sexual initiation in regions and improving contraceptive knowledge of teenagers will play a paramount role.

Keywords: early initiation of sexual intercourse, female adolescents, EDHS, Ethiopia

\section{Background}

The World Health Organization (WHO) defines an adolescent as an individual in the age group 10-19 years. ${ }^{1}$ Around 1.2 billion people -1 in 6 of the world's population - are adolescents aged between 10 and 19 years, and most of whom live in less developed regions of the world. ${ }^{2}$ For example, an estimated 5.6 million 
women aged 15-19 were living in Ethiopia as of 2014, accounting for $12 \%$ of the total female population. ${ }^{3}$

This stage is a key phase of human development characterized by rapid biological and psychosocial changes ${ }^{4}$ and this stage is often considered as a relatively healthy stage of life. However, adolescents face health risks, particularly in relation to reproduction and sexuality ${ }^{4}$ including early initiation of sexual intercourse. Early sexual initiation is defined as sexual activity that begun earlier than 18 years of age, ${ }^{5}$ and most often it is considered as a risky sexual behavior because of its adverse consequences. ${ }^{6}$ In other words, early sexual initiation is associated with adolescents' increased risks of acquiring HIV/AIDS and other STIs, having multiple partners, not using contraceptives, unwanted pregnancy, and unsafe abortions. ${ }^{7,8}$ As a result, the leading causes of death for 15 to 19-year-old girls globally are complications from pregnancy and childbirth. ${ }^{2}$ About $11 \%$ of all births worldwide are attributed to girls aged 15 to 19 years, and the vast majority of these births occur in low and middle-income countries. ${ }^{2}$ Similarly, an estimated 2.1 million adolescents were living with HIV in 2016; the great majority being in Africa. Although the overall number of HIV-related deaths has been decreasing since the peak in 2006, estimates suggest an increasing trend among adolescents. ${ }^{2}$

In African setups, an early sexual debut is high which ranging from $26.8 \%$ in Nigeria to $55 \%$ in Ghana. ${ }^{9-11}$ A complex interplay of factors like socio-cultural, religion, parent and child connectedness plays a significant role in the timing of sexual initiation to sustain adolescents remaining sexually abstinent. ${ }^{12,13}$ For instance, a comparative crosssectional study done in Nigeria depicted that religion were significant predictors of teenage pregnancy in which Muslim followers were more likely to practice it. ${ }^{14}$ The possible reason for this might be attributed to the traditional cultures and norms among Muslim followers and it might also be related to the low utilization of contraceptive method among the Muslim respondents. ${ }^{15,16}$

Like other African countries, experiences of early sexual initiation among Ethiopian female adolescents are high, ranging from $19 \%$ in Shire-Endasillasie to $20.4 \%$ in Ambo university, through to $27.6 \%$ in Legehida district of Amhara region. ${ }^{17-19}$ Unfortunately, the majority of the adolescents do not use contraceptives including condoms during early sexual intercourses. ${ }^{8,17,20}$

Substance use behaviors such as alcohol drinking, cigarette smoking and khat chewing appear to determine early initiation of sexual intercourse in female adolescents. 5,20,21 According to few local studies in Ethiopia, being a female increases the likelihood of early sexual initiation ${ }^{5,22,23}$ as well as, educational status, place of residence, income and religion are found to be factors associated with an early sexual initiation in female adolescents. ${ }^{17,19,20}$

In Ethiopia, although different studies have been conducted assessing early initiation of sexual intercourse among young women, most of these studies are institutionbased and focus adolescents in school and university settings. Therefore, this study is aimed to assess the magnitude and determinants of early sexual initiation among Ethiopian female adolescents using data from 2016 EDHS 2016. EDHS is a nationwide survey that includes both rural and urban residents from nine regions and two cities administrations of the country.

\section{Methods \\ Data Sources}

This study utilizes data from the 2016 EDHS, a nationally representative survey that collected data on basic health, demographic and socioeconomic indicators. Among 16,583 eligible women, the interview was completed for 15,683 women (15-49 years) across the nine administrative regions and two city administrations. We extracted data for all adolescent females (15-19 years), and a weighted sample of 3881 respondents were included in the study for the purpose of this analysis. Details about the DHS sampling techniques and sample size are available at http://www.dhsprogram.com/. The EDHS research protocol complies with the National Health Research Ethics Committee and Institutional Review Board guidelines.

\section{Study Variables Dependent Variable}

The study uses age at first intercourse from the survey data, and respondents who initiated sexual intercourse before the age of 18 years were considered as those experienced an "early sexual initiation."

\section{Independent Variable}

This study included place of residence (urban and rural), administrative regions, religion, education (no education, primary education, secondary, and higher educations) as well as knowledge of contraceptive methods and access to media (frequency of listening to radio and watching TV) as independent variables. Household wealth, represented by wealth index (in five categories: poorest, poorer, middle, richer and richest). Wealth index was constructed 
using data on a households' ownership of selected assets, such as television and bicycles, materials used for housing construction, and types of water access and sanitation facilities. The index placed individual households on a continuous scale relative to their wealth status.

\section{Statistical Analysis}

Extracted data were weighted so that the sample was representative of 15-19-year-old respondents in 2016 EDHS. Analyses were performed using STATA version 14. To assess the association between socio-demographic characteristics and other explanatory variables, and early sexual debut among female adolescents, a logistic regression model was employed and two steps were followed. First, each variable was entered into a binary logistic regression model. Second, variables which were significant at a p-value of less than or equals 0.25 were fitted into a multivariable logistic regression model to identify independent factors of early sexual initiation among adolescent females in Ethiopia. Statistical significance was declared at a p-value $<0.05$ in all analyses. The results from the logistic regression analyses are presented as adjusted odds ratios (OR) with 95\% confidence intervals (CIs).

\section{Results}

\section{Socio-Demographic Characteristics}

A weighted sample of 3381 Ethiopian adolescent females (15-19 years) included in the study. Nine regions and two administrative cities were included. The mean age of the respondents was $16.9(\mathrm{SD} \pm 1.36)$ years. The majority of $(76.19 \%)$ the adolescents lived in rural areas. The majority of $(83.16 \%)$ the respondents had formal education. Only a quarter $(25 \%)$ of the respondents were employed (Table 1).

\section{Sexual History of Respondents}

More than 1 out of 5 (21.9\%, 95\% CI: 20.5\%, 23.33\%) female adolescents reported having had early sexual intercourse at the time of the survey. The mean age at first sexual intercourse was $15.51(\mathrm{SD} \pm 0.058)$ years. Among adolescents who had early sexual intercourse, the majority (66.08\%) had their first sexual intercourse between the ages of 15 and 17 years. Two hundred four (27.5\%) adolescents who had early sexual intercourse had no formal education while 537 (72.5\%) had primary and above educational level.
Table I Socio-Demographic Characteristics of Adolescent Females in Ethiopia, 2016

\begin{tabular}{|c|c|c|c|}
\hline Variables & Categories & $\begin{array}{l}\text { Frequency } \\
\text { (Weighted) }\end{array}$ & Percentage \\
\hline $\begin{array}{l}\text { Place of } \\
\text { Residences }\end{array}$ & $\begin{array}{l}\text { Urban } \\
\text { Rural }\end{array}$ & $\begin{array}{l}805 \\
2576\end{array}$ & $\begin{array}{l}23.81 \\
76.19\end{array}$ \\
\hline Age Group & $\begin{array}{l}<18 \text { years } \\
\geq 18 \text { years }\end{array}$ & $\begin{array}{l}2050 \\
1331\end{array}$ & $\begin{array}{l}60.63 \\
39.37\end{array}$ \\
\hline Religion & $\begin{array}{l}\text { Orthodox } \\
\text { Protestant } \\
\text { Muslim } \\
\text { Others }\end{array}$ & $\begin{array}{l}1426 \\
847 \\
1064 \\
44\end{array}$ & $\begin{array}{l}42.18 \\
25.05 \\
31.47 \\
1.3\end{array}$ \\
\hline Sexual Partner & $\begin{array}{l}\text { Yes } \\
\text { No }\end{array}$ & $\begin{array}{l}588 \\
2793\end{array}$ & $\begin{array}{l}17.39 \\
82.61\end{array}$ \\
\hline $\begin{array}{l}\text { Employment } \\
\text { Status }\end{array}$ & $\begin{array}{l}\text { Unemployed } \\
\text { Employed }\end{array}$ & $\begin{array}{l}2558 \\
823\end{array}$ & $\begin{array}{l}75.66 \\
24.34\end{array}$ \\
\hline $\begin{array}{l}\text { Educational } \\
\text { Status }\end{array}$ & $\begin{array}{l}\text { No education } \\
\text { Primary } \\
\text { education } \\
\text { Secondary } \\
\text { Higher }\end{array}$ & $\begin{array}{l}468 \\
2148 \\
678 \\
87\end{array}$ & $\begin{array}{l}13.84 \\
63.54 \\
20.05 \\
2.57\end{array}$ \\
\hline Wealth Status & $\begin{array}{l}\text { Poorest } \\
\text { Poorer } \\
\text { Middle } \\
\text { Richer } \\
\text { Richest }\end{array}$ & $\begin{array}{l}478 \\
558 \\
638 \\
716 \\
991\end{array}$ & $\begin{array}{l}14.14 \\
16.50 \\
18.87 \\
21.18 \\
29.31\end{array}$ \\
\hline $\begin{array}{l}\text { Administrative } \\
\text { Regions }\end{array}$ & $\begin{array}{l}\text { Tigray } \\
\text { Afar } \\
\text { Amhara } \\
\text { Oromiya } \\
\text { Somali } \\
\text { Benishangul } \\
\text { SNNPR } \\
\text { Gambella } \\
\text { Harari } \\
\text { Addis Ababa } \\
\text { Dire Dawa }\end{array}$ & $\begin{array}{l}276 \\
29 \\
767 \\
1234 \\
105 \\
34 \\
681 \\
9 \\
8 \\
217 \\
20\end{array}$ & $\begin{array}{l}8.16 \\
0.86 \\
22.68 \\
36.5 \\
3.1 \\
1.01 \\
20.14 \\
0.27 \\
0.24 \\
6.42 \\
0.59\end{array}$ \\
\hline
\end{tabular}

Abbreviation: SNNPR, Southern nations, nationalities and people region.

\section{Risky Behaviors Associated with Early Sexual Initiation}

About $7.4 \%$ of the total adolescents had ever chewed chat. Of which, $15 \%$ a history of had early sexual intercourse. Similarly, among adolescent females who had initiated sex earlier, 35.2\% had ever experienced drinking alcohol. Among adolescents who had sexual partners (832), 11\% (90 of the adolescents had multiple sexual partners (Table 2)). 
Table 2 Risky Behaviors Associated with Early Sexual Initiation Among Female Ethiopian Adolescents, 2016

\begin{tabular}{|l|l|l|l|}
\hline Variables & Categories & Frequency & Percentage \\
\hline Ever chewed khat & $\begin{array}{l}\text { No } \\
\text { Yes }\end{array}$ & $\begin{array}{l}3131 \\
250\end{array}$ & $\begin{array}{l}92.6 \\
\end{array}$ \\
\hline Ever Drink alcohol & Yes & 2352 & 69.6 \\
& No & 1029 & 30.4 \\
\hline Number of Sexual & $\begin{array}{l}\text { One } \\
\text { Two and } \\
\text { above }\end{array}$ & 742 & 89.2 \\
& 90 & 10.8 \\
\hline
\end{tabular}

\section{Determinants of Early Sexual Initiation} Among Adolescent Females in Ethiopia

In bi-variable analyses, almost all variables were associated with early initiation of sexual intercourse among adolescent females in Ethiopian. After controlling for the possible confounders in multivariable analysis, variables including administrative region, religion, educational status, history of chat chewing and alcohol use, knowledge of family planning methods, and wealth status were associated with early initiation sexual intercourse. Adolescent females living in Amhara and Gambella regions were more likelihood to have early sexual intercourse as compared to those living in Addis Ababa city (Amhara: AOR $=2.30,95 \%$ CI: 1.30, 4.09, Gambella: AOR $=4.89,95 \%$ CI: $1.08,22.07)$. Being in primary, secondary, and higher education level decreases the odds of early sexual debut compared to those with no formal education (primary $\mathrm{AOR}=0.44,95 \% \mathrm{CI}: 0.35,0.56$, secondary $\mathrm{AOR}=$ $0.19,95 \%$ CI: $0.13,0.28$, and higher $\mathrm{AOR}=0.31,95 \%$ CI: $0.15,0.63)$. The study reveals being from Muslim religion follower increased the likely of early sexual debut when compared with those from orthodox followers $(\mathrm{AOR}=1.76,95 \% \mathrm{CI}: 1.24,2.49)$. With increasing the class of their wealth status from poorer to the richest, the likelihood of early sexual initiation was found to be decreasing (i.e., poorer: AOR $=0.66,95 \%$ CI: $(0.49$, 0.88 ), middle: $\mathrm{AOR}=0.57,95 \% \mathrm{CI}: 0.42,0.76$, richer: $\mathrm{AOR}=0.40,95 \% \mathrm{CI}: 0.29,0.55$, and richest: $\mathrm{AOR}=0.49$, $95 \%$ CI: $0.32,0.73)$. Adolescent females with a history of khat chewing were 2.02 times likely to initiate sexual intercourse earlier as compared to those did not chew khat $(\mathrm{AOR}=2.02,95 \% \mathrm{CI}: 1.47,2.77)$. Having a history of drinking alcohol increased the likelihood of earlier sexual intercourse by 1.83 times as compared to those who did not drink (AOR $=1.83,95 \%$ CI: 1.35, 2.48).
Respondents who were knowledgeable about any type of family planning methods were 4.47 times more likelihood to initiate sexual intercourse earlier than those without the knowledge (AOR $=4.47,95 \%$ CI: 2.22, 8.99) (Table 3).

\section{Discussion}

This study showed that $21.9 \%$ of respondents were involved in early sexual intercourse, which perhaps is comparable with findings from "pocket" studies in the country ranging from $19 \%$ to $25.3 \%{ }^{17,19,22}$ In contrast, this finding is higher than the findings from Ghana (55\%) and Tanzania (48.7\%). ${ }^{9,10}$ This discrepancy might be due to the differences in cultural norms and social values that discourage premarital sex in Ethiopia. Perhaps other unstudied factors might have contributed to this difference. Religion is found to be associated with early sexual initiation; the Muslim followers are more likelihood to initiate sex early as compared to Orthodox Christianity followers. However, evidence from Ambo University indicated that Orthodox Christianity followers were more likely to initiate sex. ${ }^{17}$ The reason might be the belief in the religion that enhances early marriage to protect virginity and obey rules of the religion.

Having primary and above educational level is found to be protective for early marriage as compared to those with no education. This is supported by evidences from eight African countries, ${ }^{24}$ and Ambo town and Addis Ababa city in Ethiopia. ${ }^{20,25}$ This could be a function of maturity as educational level advances, and might also be due to exposure to information, education and communication on the topic. Wealth status was significantly associated with early initiation of sexual intercourse possibly portrays that female with better wealth index were less likely to engage in early sex. ${ }^{9}$ Indeed, economically poor females engage in earlier sexual intercourse in exchange for money and other benefits. ${ }^{8}$ In other words, poverty contributes to the deterioration of adolescents' future by leaving lasting sequels from sexual and reproductive complications. That may mean, adolescent females with knowledge on any methods of contraceptive initiate sex early. ${ }^{9}$ Having knowledge about contraceptive may avoid fear of unwanted pregnancy and increase confidence to start sexual activity at early ages. In line with other studies, ${ }^{10,11,24,26}$ substance use increases the likelihood of early sexual debut. ${ }^{5,22,23,25}$ This may be due to the fact that alcohol or khat can alter the normal behaviors and increase disorientation and loss of self-control that can lead adolescents to early sexual act and other risky sexual activities. Furthermore, a study conducted on Khat and 
Table 3 Factors Associated with Early Sexual Initiation Among Female Ethiopian Adolescents, 2016

\begin{tabular}{|c|c|c|c|c|c|}
\hline \multirow[t]{2}{*}{ Predictor Variables } & \multirow[t]{2}{*}{ Categories } & \multicolumn{2}{|c|}{ Early Sexual Initiation } & \multirow[t]{2}{*}{ COR } & \multirow[t]{2}{*}{ AOR } \\
\hline & & No & Yes & & \\
\hline \multirow[t]{2}{*}{ Place of Residences } & Urban & 703 & 102 & I & I \\
\hline & Rural & 1937 & 639 & $2.270(1.81,2.85)^{*}$ & $0.92(0.6 \mathrm{I}, \mathrm{I} .38)$ \\
\hline \multirow[t]{4}{*}{ Religion } & Orthodox & 1118 & 308 & I & I \\
\hline & Protestant & 730 & 117 & $0.58(0.46,0.73)^{*}$ & $1.27(0.88,1.85)$ \\
\hline & Muslim & 722 & 309 & $1.48(1.24,1.78)^{*}$ & $1.76(1.24,2.49)^{*}$ \\
\hline & Others & 37 & 7 & $0.74(0.33,1.64)$ & $0.69(0.28,1.65)$ \\
\hline \multirow[t]{4}{*}{ Educational Status } & No education & 265 & 204 & I & I \\
\hline & Primary education & 1685 & 462 & $0.356(0.29,0.44)^{*}$ & $0.44(0.35,0.56)^{*}$ \\
\hline & Secondary & 615 & 63 & $0.13(0.097,0.18)^{*}$ & $0.19(0.13,0.28)^{*}$ \\
\hline & Higher & 76 & 11 & $0.19(0.099,0.37)^{*}$ & $0.31(0.15,0.63)^{*}$ \\
\hline \multirow[t]{5}{*}{ Wealth Status } & Poorest & 300 & 178 & I & I \\
\hline & Poorer & 391 & 167 & $0.7 \mathrm{I}(0.55,0.93)^{*}$ & $0.66(0.49,0.88)^{*}$ \\
\hline & Middle & 482 & 156 & $0.54(0.42,0.70)^{*}$ & $0.57(0.42,0.76)^{*}$ \\
\hline & Richer & 604 & 112 & $0.3 \mathrm{I}(0.24,0.4 \mathrm{I})^{*}$ & $0.40(0.29,0.55)^{*}$ \\
\hline & Richest & 863 & 128 & $0.25(0.19,0.32)^{*}$ & $0.49(0.32,0.73)^{*}$ \\
\hline \multirow[t]{2}{*}{ Ever Chewed Khat } & No & 2501 & 630 & I & I \\
\hline & Yes & 139 & 111 & $3.15(2.42,4.10)^{*}$ & $2.02(1.47,2.77)^{*}$ \\
\hline \multirow[t]{2}{*}{ Ever Drink Alcohol } & No & 1872 & 480 & & \\
\hline & Yes & 768 & 261 & $\mathrm{I} .33(1.1 \mathrm{I}, \mathrm{I} .57)^{*}$ & $\mathrm{I} .83(\mathrm{I} .35,2.48)^{*}$ \\
\hline \multirow[t]{2}{*}{ Knowledge of Family Planning } & No & 90 & 11 & I & I \\
\hline & Yes & 2550 & 730 & $2.3(1.22,4.25)^{*}$ & $4.47(2.22,8.99)^{*}$ \\
\hline \multirow[t]{11}{*}{ Administrative Regions } & Addis Ababa & 197 & 20 & I & I \\
\hline & Tigray & 211 & 64 & $3.01(1.76,5.16)^{*}$ & $\mathrm{I} .81(0.97,3.39)$ \\
\hline & Afar & 16 & 14 & $8.44(3.58,19.89)^{*}$ & $2.56(0.97,6.8)$ \\
\hline & Amhara & 547 & 220 & $3.97(2.44,6.45)^{*}$ & $2.30(1.30,4.09)^{*}$ \\
\hline & Oromiya & 956 & 279 & $2.88(1.78,4.65)^{*}$ & $\mathrm{I} .40(0.79,2.5 \mathrm{I})$ \\
\hline & Somali & 79 & 26 & $3.29(1.74,6.23)^{*}$ & $1.51(0.70,3.29)$ \\
\hline & Benishangul & 26 & 8 & $3.18(1.28,7.87)^{*}$ & $1.95(0.73,5.24)$ \\
\hline & SNNPR & 579 & 101 & $1.73(1.04,2.87)^{*}$ & $1.18(0.64,2.19)$ \\
\hline & Gambella & 6 & 3 & $5.47(1.33,22.54)^{*}$ & $4.89(1.08,22.07)^{*}$ \\
\hline & Harari & 6 & 2 & $3.11(0.56,17.33)$ & $2.09(0.33,13.20)$ \\
\hline & Dire Dawa & 17 & 4 & $2.37(0.72,7.82)$ & $1.57(0.44,5.53)$ \\
\hline \multirow[t]{3}{*}{ Frequency of Watching TV } & Not at all & 1707 & 590 & I & I \\
\hline & $<$ I a week & 384 & 88 & $0.66(0.5 \mathrm{I}, 0.85)^{*}$ & $0.88(0.66,1.18)$ \\
\hline & $\geq 1$ week & 549 & 63 & $0.33(0.25,0.44)^{*}$ & $0.68(0.46,1.01)$ \\
\hline \multirow[t]{3}{*}{ Frequency of Listening Radio } & Not at all & 1620 & 522 & I & I \\
\hline & $<1$ a week & 536 & 119 & $0.69(0.55,0.86)^{*}$ & $\mathrm{I} .04(0.8 \mathrm{I}, \mathrm{I} .33)$ \\
\hline & $\geq$ I week & 484 & 100 & $0.64(0.50,0.80)^{*}$ & $1.22(0.92,1.60)$ \\
\hline
\end{tabular}

Note: *Statistically significant at $\mathrm{p}<0.05$.

Abbreviations: AOR, adjusted odds ratio; COR, crudes odds ratio; SNNPR, Southern nations, nationalities and people region.

alcohol use and risky sex behaviour among in-school and out-of-school youth in Ethiopia revealed that substance use is significantly and independently associated with risky sexual behavior. ${ }^{27}$ Hence, national HIV/AIDS prevention and control strategies and programmes directing adolescents ought to take into account substance use as one of the important factors playing paramount role in risky sexual behaviours like early sexual debut. 


\section{Strengths and Limitations}

The study utilized a weighted sample of data from a nationwide survey, which could be considered as strength and could enhance representativeness. On the other hand, this study may suffer from a recall bias sexual activity was a self-reported event.

\section{Conclusion}

A significant proportion of adolescent females initiate early sexual intercourse in Ethiopia and multifaceted factors appear to determine their sexual experiences. Administrative region, religion, educational status, history of chat chewing and alcohol use, knowledge of family planning methods, and wealth status were associated with early initiation of sexual intercourse. Contextualized interventions including strengthening information, education and communication on adverse consequences of early sexual initiation in regions and improving contraceptive knowledge of teenagers will play a paramount role. Health promotion that supports teenagers refrain from substance use is also highly recommended.

\section{Abbreviations}

AOR, adjusted odds ratio; CI, confidence interval; COR, crude odds ratio; CSA, Central Statistical Agency; EDHS, Ethiopian Demographic and Health Survey; WHO, World Health Organization.

\section{Data Sharing Statement}

This research uses national survey data that is publicly available for research collected by the Central Statistical Agency [Ethiopia] and ICF. National Demographic and Health Survey of Ethiopia in 2016 [Dataset]. Accessed (http://idhsdata.org). The datasets used and/or analyzed in the current study are available from the corresponding author on reasonable request.

\section{Ethics and Consent Statement}

The 2016 EDHS data are available to the general public by request in different formats from the Measure DHS website [http://idhsdata.org]. We applied the measure DHS by briefly stating the objectives of the study and got the permission to download the dataset in SPSS format. Permission letter for access to database was received from Measure DHS, ICF International, Rockville, Maryland, USA.

\section{Acknowledgment}

We would like to express our deepest gratitude to Measure DHS, ICF International, Rockville, Maryland, USA, for providing the data for the analysis.

\section{Author Contributions}

Conceived and designed the study: ET and BTM; Methodology: BTM, ET and GF; Analysis: BT and ET; Drafting the manuscript and made revisions: BTM, ET, AAA and GF. All authors contributed to data analysis, drafting or revising the article, gave final approval of the version to be published, and agreed to be accountable for all aspects of the work.

\section{Funding}

This research received no external funding.

\section{Disclosure}

The authors report no conflicts of interest in this work.

\section{References}

1. Organization WH. Programming for adolescent health and development: Report of a WHO/UNFPA/UNICEF study group on programming for adolescent health: World Health Organization; 1999.

2. WHO. Adolescents:health risks and Solutions; 2018.

3. IPPF, Institute G. Sexual and Reproductive Health of Young Women in Ethiopia; 2014.

4. Denno DM, Hoopes AJ, Chandra-Mouli V. Effective strategies to provide adolescent sexual and reproductive health services and to increase demand and community support. $J$ Adolescent Health. 2015;56(1):S22-S41. doi:10.1016/j.jadohealth.2014.09.012

5. Mazengia F, Worku A. Age at sexual initiation and factors associated with it among youths in North East Ethiopia. Ethiop $J$ Health Develop. 2009;23:2.

6. Fetene N, Mekonnen W. The prevalence of risky sexual behaviors among youth center reproductive health clinics users and non-users in Addis Ababa, Ethiopia: a comparative cross-sectional study. PLoS One. 2018;13(6):e0198657. doi:10.1371/journal.pone.0198657

7. Baumgartner JN, Geary CW, Tucker H, Wedderburn M. The influence of early sexual debut and sexual violence on adolescent pregnancy: a matched case-control study in Jamaica. Int Perspect Sex Reprod Health. 2009;35(01):21-28. doi:10.1363/3502109

8. Mavhandu-Mudzusi AH, Tesfay Asgedom T. The prevalence of risky sexual behaviours amongst undergraduate students in Jigjiga University, Ethiopia. Health Sa Gesondheid. 2016;21(1):179-186. doi:10.1016/j.hsag.2015.11.002

9. Asante O, Nketiah-Amponsah E, Andoh-Arthur J, Boafo IM, Ampaw S. Correlates of early sexual debut among sexually active youth in Ghana. Int $Q$ Community Health Educ. 2018;39(1):9-17. doi:10.1177/0272684X18811016

10. Mmbaga EJ, Leonard F, Leyna GH. Incidence and predictors of adolescent's early sexual debut after three decades of HIV interventions in Tanzania: a time to debut analysis. PLoS One. 2012;7(7): e41700. doi:10.1371/journal.pone. 0041700

11. Olufemi AT, Paulin OI, Akinbode OO. Prevalence and predictors of early sexual debut among adolescents in Ogbomoso, Nigeria. Am $J$ Public Health. 2018;6(3):148-154. doi:10.12691/ajphr-6-3-4 
12. Millera CBB, Galbraith K. Family relationships and adolescent pregnancy risk: a research synthesis. Dev Rev. 2001;21:1. doi:10.1006/ drev.2000.0513

13. Kamal SM. Adolescent motherhood in Bangladesh: evidence from 2007 BDHS data. Can Stud Popul. 2012;39(1-2):63-82. doi:10.25336/P6KG7R

14. Amoran OE. A comparative analysis of predictors of teenage pregnancy and its prevention in a rural town in Western Nigeria. Int $J$ Equity Health. 2012;11(1):37. doi:10.1186/1475-9276-11-37

15. Alemayehu M, Lemma H, Abrha K, et al. Family planning use and associated factors among pastoralist community of afar region, eastern Ethiopia. BMC Women's Health. 2016;16(1):39. doi:10.1186/ s12905-016-0321-7

16. Walelign D, Mekonen A, Netsere M, Tarekegn M. Modern contraceptive use among orthodox christian and muslim women of reproductive age group in Bahir Dar City, North West Ethiopia: comparative cross sectional study. Open J Epidemiol. 2014;4 (04):235. doi:10.4236/ojepi.2014.44030

17. Bayissa D, Mebrahtu G, Bayisa G, Mekuanint Y. Assessment of early sexual initiation and associated factors among ambo university undergraduate students, Ambo, Ethiopia. J Health Med Nurs. 2016; 25:35-40.

18. Wassachew AK. Early Sexual Debut and Associated Factors Among High School Adolescents Legehida District, Amahara Regional State. Ethiopia: Haramaya University; 2015.

19. Ayalew A, Abreha K, Shumey A, Berhane K. Magnitude and predictors of early sexual debut among high and preparatory school students in northern Ethiopia: a school-based crosssectional study. J Health Educ Res Develop. 2015;1-8.
20. Gizaw A, Jara D, Ketema K. Risky sexual practice and associated factors among high school adolescent in Addis Ababa, Ethiopia, 2014. Fam Med Med Sci Res. 2014;3(141):2.

21. Amare T, Yeneabat T, Amare Y. A systematic review and meta-analysis of epidemiology of risky sexual behaviors in college and university students in Ethiopia, 2018. J Environ Public Health. 2019;2019.

22. Girma D, Hailu G, Ayana M, Ketema K. Factors early sexual initiation among governmental preparatory school students, Addis Ababa, Ethiopia. J Community Med Health Educ. 2015;5(1):333.

23. Kassa GM, Tsegay G, Abebe N, et al. Early sexual initiation and associated factors among Debre Markos University Students, North West Ethiopia. Sci J Clin Med. 2015;4(5):80. doi:10.11648/j. sjcm.20150405.11

24. Peltzer K. Early sexual debut and associated factors among in-school adolescents in eight African countries. Acta Paediatr. 2010;99 (8):1242-1247. doi:10.1111/j.1651-2227.2010.01874.x

25. Nigatu DT, Seme A, Fituma S, Segni MT. Sexual initiation and associated factors among young women in West Shoa, Ambo Town, Ethiopia: a community-based cross-sectional study. BMC Women's Health. 2018;18(1):76. doi:10.1186/s12905-018-0563-7

26. Durowade KA, Babatunde OA, Omokanye LO, et al. Early sexual debut: prevalence and risk factors among secondary school students in Ido-ekiti, Ekiti state, South-West Nigeria. Afr Health Sci. 2017;17 (3):614-622. doi:10.4314/ahs.v17i3.3

27. Kebede Derege AA, Mitike G, Enquselassie F, et al. Khat and alcohol use and risky sex behaviour among in-school and out-of-school youth in Ethiopia. 2005.
International Journal of Women's Health

\section{Publish your work in this journal}

The International Journal of Women's Health is an international, peerreviewed open-access journal publishing original research, reports, editorials, reviews and commentaries on all aspects of women's healthcare including gynecology, obstetrics, and breast cancer. The

\section{Dovepress}

manuscript management system is completely online and includes a very quick and fair peer-review system, which is all easy to use. Visit http://www.dovepress.com/testimonials.php to read real quotes from published authors. 